
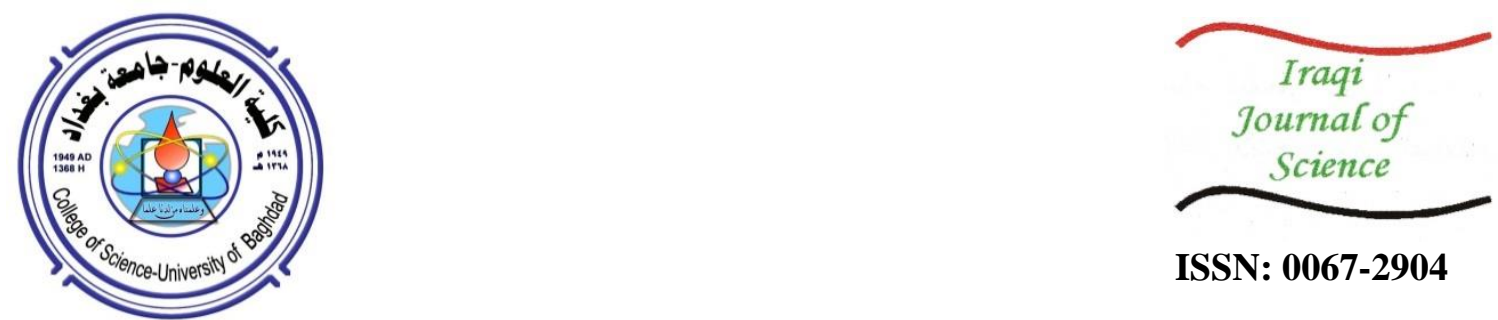

ISSN: 0067-2904

\title{
Role of Kisspeptin Gene Polymorphism in Idiopathic Male Infertility in Iraq
}

\author{
Firas Kareem Al-Kalabi ${ }^{1}$, Adnan F Al-Azzawie ${ }^{2}$, Estabraq AR. Al-Wasiti ${ }^{3 *}$ \\ ${ }^{1}$ Iraqi Ministry of Education, Wasit, Iraq \\ ${ }^{2}$ Department of Biology, College of Science, Tikrit University / Tikrit/Iraq \\ ${ }^{3}$ Department of Chemistry and Biochemistry, College of Medicine, Al-Nahrain University, Baghdad/ Iraq
}

Received: 31/1/2021 Accepted: 16/4/2021

\begin{abstract}
This case control study aimed to determine single nucleotide polymorphisms (SNPs) in the Kisspeptin (KISS1) gene in males with idiopathic infertility and their association with sex hormones and semen quality. The study included a total of 60 infertile and 30 healthy fertile males. Our results show that the level of the measured hormones (LH, FSH, Testosterone, Prolactin and Kisspeptin-54) were higher in the control group than in the male infertile group at $\mathrm{p}<0.05$. We used polymerase chain reaction restriction fragment length polymorphism (PCR-RELP) for the genotyping of KISS1 position rs35431622 (Q36R) KISS1, which showed three different genotypes of different sizes; a wild-type homozygous AA of $233 \mathrm{bp}$ and a heterozygous AG that has digestion products of 233,161 , and $72 \mathrm{bp}$. The AG was more frequent in the patients group which also had high $O R$ value of $G$ allele (3.105). While for the $\mathrm{rs} 4889(\mathrm{C} / \mathrm{G})$, there was a correlation between the CC genotype and the patients group, but it was non-significant. Patients had an OR value of 2.5 for the CC genotype with 95\% CI: $0.21-29.26$, whereas the OR value for the C allele was 1.14 with $95 \%$ CI: $0.613-2.135$. In conclusion, variations in SNPs of the KISS1 gene may be considered as a risk factor for idiopathic male infertility in Iraqi population.
\end{abstract}

Keywords: Kisspeptin, infertility, rs35431622 SNP, rs4889 SNP.

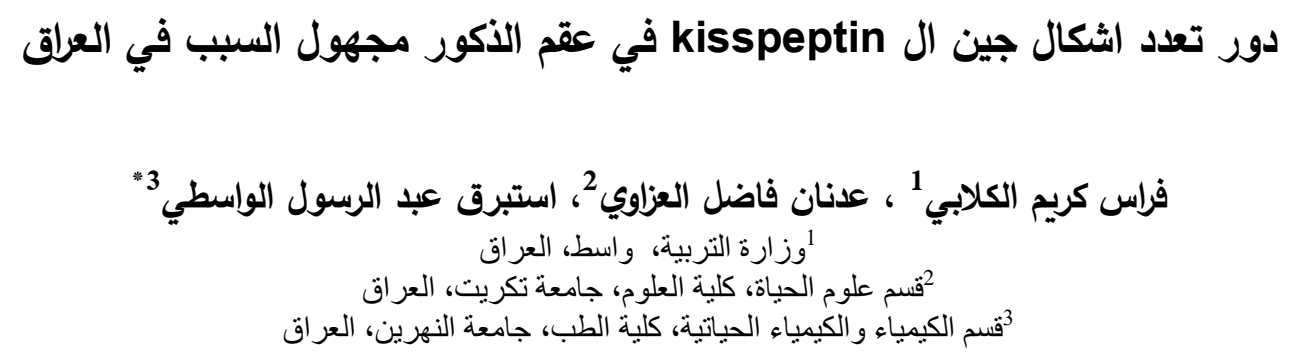

\footnotetext{
الخلاصة

هدف هذه الدراسة تحديد تعدد اشكال النكليوتيدة المفردة في جين ال KISS1 في الذكور المصابين بالعقر

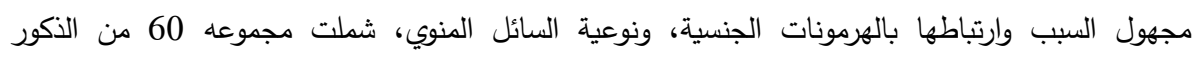

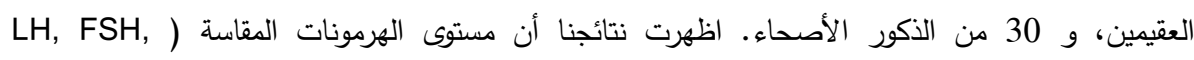

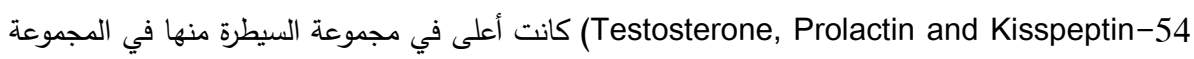

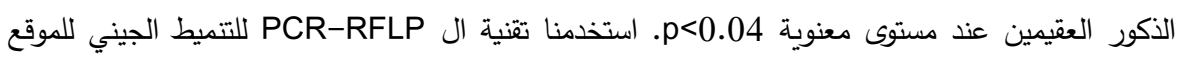

*Email: alwasiti@colmed-alnahrain.edu.iq 


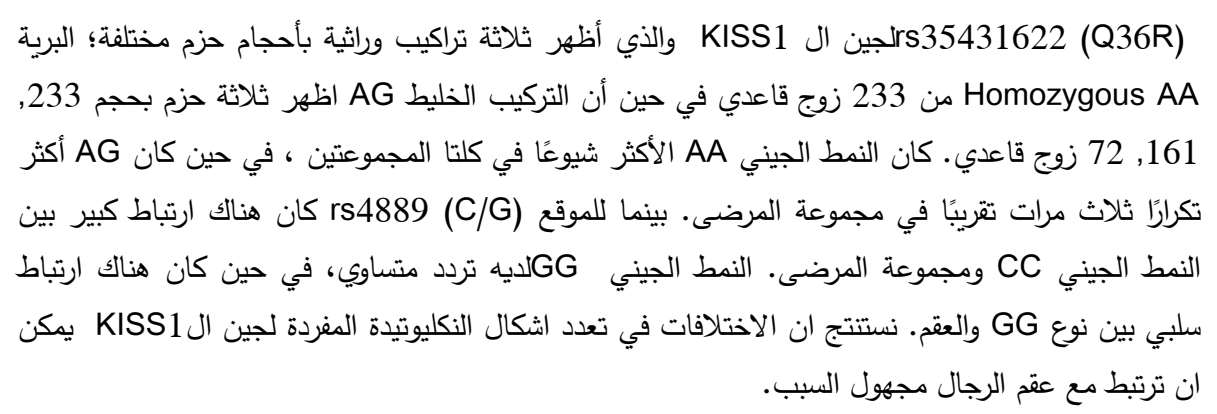

\section{Introduction}

Infertility is a common worldwide problem that effects about $10 \%$ of couples at reproductive age, with its associated medical, social, and legal consequences [1]. The World Health Organisation (WHO) defines infertility as the inability of couples to conceive after one year of regular unprotected sexual intercourse [2]. It is either primary, where the female partner never conceived, or secondary, when there is a history of a previous conception but no more new pregnancies [1].

Aetiologically, infertility can be due to factors in males, females, or both of them. Male factors contribute alone or in combination with female ones to $25-30 \%$ and $50 \%$ of infertility cases, respectively [3]. The list of male pathologies is long and includes, but not limited to, cryptorchidism, testicular hypotrophy, testicular cancer, known genetic factors (e.g., karyotype anomalies, cystic fibrosis, thalassemia), varicocele, testicular trauma, reproductive tract infections, and testicular torsion [4].

Many males suffer from pathological problems that are the primary cause of infertility, but unfortunately, they are not properly diagnosed and treated [5]. Additionally, a significant subset $(\sim 15 \%)$ of infertile males are clinically healthy with normal semen parameters and normal sex endocrine investigations, but are known as having unexplained or idiopathic infertility [6]. Different factors have been hypothesized as causes of idiopathic infertility, such as immunological factors, oxidative stress, fertilisation defects, and genetic factors [6]. The later factors have received the attention of scientists and variations in single nucleotides in genes, known as single nucleotide polymorphisms (SNP), have been in the heart of the researches [7-9]. Several genetic variations are occurring in the genes encoding for gonadotropin hormone receptors. These polymorphisms are differently distributed among human populations, with different genotype frequencies in the same population [10]. SNPs in genes regulating the hypothalamic-pituitary-gonadal axis were extensively studied, including those in the KISS1 gene and its KISS1R receptor. Kisspeptin is a protein synthesised by the hypothalamus and positively regulates the hypothalamic-pituitary-gonadal axis; thus, it controls puberty and sex organs function through stimulating the secretion of the luteinizing hormone ( $\mathrm{LH})$, follicle stimulating hormone (FSH), prolactin, and testosterone [8].

Kisspeptin is also involved in peripheral activities, such as testicular steroidogenesis and spermatogenesis [11]. KISSI gene is located on the long arm of chromosome 1. It has four exons and encodes a 145-amino acid peptide that is cleaved into four shorter peptides, namely KP-54, KP-14, KP-13, and KP-10, of 54, 14, 13 and 10 amino acids, respectively. These forms all share a common C-terminal decapeptide (KP10), which is required for binding with its receptor KISS1R (also known as GPR54) [12].

Given its vital functions, KISS1 gene SNPs were studied in precocious puberty, polycystic ovarian syndrome, and male infertility in different clinical and geographical settings [13-15]. To the best of our knowledge, no study was conducted, at least in Iraq, to examine the role of KISS1 gene SNPs in idiopathic male infertility. In this work, we examined SNPs in the KISS1 gene in males with idiopathic infertility and their association with sex hormones (LH, FSH, Prolactin, Testosterone) and semen quality. 


\section{Subjects, materials, and methods Study subjects}

This case- control study includes a total of 90 males (60 patients +30 controls) with an age range of 20-45 years. The patient group has a history of infertility and consulted the outpatient clinics at Al-Nahrain High Institute for Infertility Diagnosis and Assisted Reproductive Technologies over the period from the 1st of January 2018 to the 1st of January 2019.

Patients were included in this study according to the following criteria of idiopathic infertility: infertile as defined by the WHO [2], normal seminal fluid analysis performed based on WHO guidelines [16], normal endocrine investigations, regular sexual intercourse, no history of chronic diseases, and exclusion of female factors. The control group included 30 healthy fertile with normal semen analysis and endocrine investigations.

\section{Materials and methods}

Five milliliters of peripheral venous blood were collected from the study subjects at 9 A.M. Each sample was divided into two aliquots; one ml was transferred into EDTA containing tube and stored at $-20^{\circ} \mathrm{C}$ until further DNA analysis, whereas the remaining amount was transferred into a plain tube, from which serum was obtained by centrifugation for 5 minutes at $5000 \mathrm{rpm}$ and stored at $-20^{\circ} \mathrm{C}$ until analyzed for hormones ( $\mathrm{LH}, \mathrm{FSH}$, Prolactin, Testosterone) and kisspeptin peptide.

\section{Hormonal assays}

The serum hormones were measured using MiniVidas ${ }^{\circledR}$ machine (BioMérieux, France) using its costume kit.

The Kisspeptin -54 was measured in serum using enzyme-linked immunosorbent assay (ELISA) technology utilising a kit (Canine Kisspeptin 1 (KISS1) SL0103Ca ) supplied by Sunlong Biotech Co. Ltd., China.

\section{SNP genotyping}

DNA extraction was performed using a Qiagen ${ }^{\circledR}$ QIAamp DNA Blood Mini Kit (cat no, 51104, Qiagen ${ }^{\circledR}$, Germany) following the supplier instructions strictly.

The DNA samples were then genotyped using two methods, each specific for a SNP. In the first method, KISS1 gene SNP rs35431622 (Q36R) was tested using PCR followed by Restriction Fragment Length Polymorphism (RFLP), as applied before [17]. The sequences of the primer were forward 5'-CATCCCAGCTAAGGTGATCGT-3' and reverse 5'-CAG CTG GCTTCCTCTCGGT-3'. PCR was performed in a total volume of $20 \mu 1$, consisting of $1 \mu 1$ of each primer, $10 \mu$ of PCR master mix, $4 \mu$ l of each of molecular grade and DNA template (20ng/ $\mu \mathrm{l})$. Applied Biosystems thermocycler (Singapore) was used according to the following conditions: initial denaturation phase at $94^{\circ} \mathrm{C}$ for $3 \mathrm{~min}$, followed by 35 cycles of $94^{\circ} \mathrm{C}, 60^{\circ} \mathrm{C}$, and $72^{\circ} \mathrm{C}$ each for $30 \mathrm{sec}$, with a final extension phase of $72^{\circ} \mathrm{C}$ for $3 \mathrm{~min}$. The PCR product (233bp) was digested by incubation with the 10 units of NaeI restriction enzymes for $3 \mathrm{hr}$ and the digestion outcome was visualized under ultraviolet light (Gel Documentation System ${ }$, Korea). Various genotypes showed DNA sizes of 233bp, 161bp, and 72bp.

In the second method, KISSR1 gene codon 81 (307, 204bp)was genotyped by utilizing the Amplification Refractory Mutation System-PCR (ARMS-PCR) assay [18], using TCCGGGAGCCCCCAGCAGC as a common forward primer, reverse primer 1 CACTGCCCCGCACCTGCG for $\mathrm{C}$ allele, and reverse primer 2 GCCTCGGGTTGGAAGCTC for $\mathrm{G}$ allele. Two reactions were set, one for the $\mathrm{C}$ allele and the other for the G allele. Each tube contained $10 \mu 1$ of PCR master mix, $4 \mu$ l of DNA template (20ng/ $\mu \mathrm{l}$ ), $1 \mu \mathrm{l}$ of each primer (forward and reverse), and $1 \mu \mathrm{l}$ of each primer (forward and reverse) specific for each allele ( $\mathrm{C}$ or $\mathrm{G})$. Each tube was mixed well and subjected to the following thermal conditions specific for each allele; for KISSR1 207, the conditions were pre denaturation phase at $95^{\circ} \mathrm{C}$ for $3 \mathrm{~min}$, followed by 10 cycles of $95^{\circ} \mathrm{C}, 70^{\circ} \mathrm{C}$ and $72^{\circ} \mathrm{C}$ each for $45 \mathrm{sec}$ that is followed by another 30 cycles of $95^{\circ} \mathrm{C}, 60^{\circ} \mathrm{C}$ and $72^{\circ} \mathrm{C}$ each for $45 \mathrm{sec}$, with 
final extension phase of $72^{\circ} \mathrm{C}$ for $5 \mathrm{~min}$. While for the KISSR1 304, similar cycling conditions were applied, except that the annealing temperature was $65^{\circ} \mathrm{C}$ for the first 10 cycles and $55^{\circ} \mathrm{C}$ for the second 30 cycles.

\section{Seminal fluid analysis}

This analysis was performed after 2-7 days of sexual abstinence according to the WHO instructions. The seminal fluid was collected into a sterile container and analysed within one hour after collection. The normal range for semen parameters was adopted as described by the WHO guidelines [16].

\section{Statistical analysis}

The statistical analysis was performed with SPSS statistics software (version 24.0, Chicago, USA). Chi-squared test was performed to study the correlation between variables, while unpaired student t-test was applied to compare between the groups for the whole study. The level of statistical significance was set to p-value lower than 0.05 .

\section{Results}

\section{General Characteristic of Study groups}

The results of our study showed that the study groups were similar with regard to their age and body mass index ( $>0.05)$, as detailed in Table 1 .

Table 1-Demographic and clinical characteristics of the studied population of patients with....

\begin{tabular}{|c|c|c|c|}
\hline Parameter & Patients group & Control group & $\boldsymbol{P}$ Value \\
\hline Age (Mean \pm SD) Year & $36.87 \pm 11.7$ & $37.06 \pm 14.18$ & $>0.05$ \\
& $20-45$ years & $25-5$ & \\
\hline Duration of infertility /Years & 26 & N/A & $>0.05$ \\
$\mathbf{0 - 5}$ years & 16 & & \\
$\mathbf{5 - 1 0}$ years & 18 & & $>0.05$ \\
\hline BMears & $25.73 \pm 2.2$ & $27.09 \pm 4.96$ & \\
\hline
\end{tabular}

\section{Hormonal study}

As outlined in Table 2, it is clear that the level of each of the measured hormones (LH, FSH, testosterone, prolactin and kisspeptin-54) was higher in the control group than the infertile group $(\mathrm{p}<0.04)$. Kisspeptin-54 showed the greatest increase in the control group when compared to infertile group, followed by testosterone, FSH, LH and prolactin, respectively. The mean values of the hormones in the study population and the $p$ values are depicted in Table 2.

Table 2-Levels of the LH, FSH, Testosterone, Prolactin and Kisspeptin-54) hormones in studied groups

\begin{tabular}{|c|c|c|c|}
\hline Parameter & $\begin{array}{c}\text { Control (No. 60) Mean } \pm \\
\text { SD }\end{array}$ & $\begin{array}{c}\text { Patients (No. 30 } \\
\text { Mean } \pm \text { SD }\end{array}$ & P value \\
\hline Kisspeptin-54 $(\mathbf{n g} / \mathbf{m l})$ & $195.3 \pm 6.5$ & $136.4 \pm 8.4$ & $0.0005^{* *}$ \\
\hline Testosterone $(\mathbf{n g} / \mathbf{m l})$ & $8.5 \pm 6.5$ & $4.7 \pm 1.5$ & $0.0021^{* *}$ \\
\hline FSH $(\mathbf{m} \boldsymbol{\mu} / \mathbf{m l})$ & $5.8 \pm 7.0$ & $3.0 \pm 1.3$ & $0.0347^{* *}$ \\
\hline LH $(\mathbf{m} \boldsymbol{\mu} / \mathbf{m l})$ & $5.4 \pm 3.5$ & $3.7 \pm 1.9$ & $0.0178^{* *}$ \\
\hline Prolactin $(\mathbf{n g} / \mathbf{m l})$ & $14.7 \pm 8.4$ & $10.7 \pm 4.8$ & $0.0184^{* *}$ \\
\hline
\end{tabular}

\section{Genotyping and allele frequencies of KISS1}

Using the RFLP for the genotyping of KISS1 position rs35431622 (Q36R) KISS1 showed three different genotypes of different sizes after enzyme digestion; a wild-type homozygous AA of $233 \mathrm{bp}$ and a heterozygous AG that has a digestion product of three different sizes of 233, 161, 72 bp. Examples of the RFLP genotypes are shown in Figure 1. 


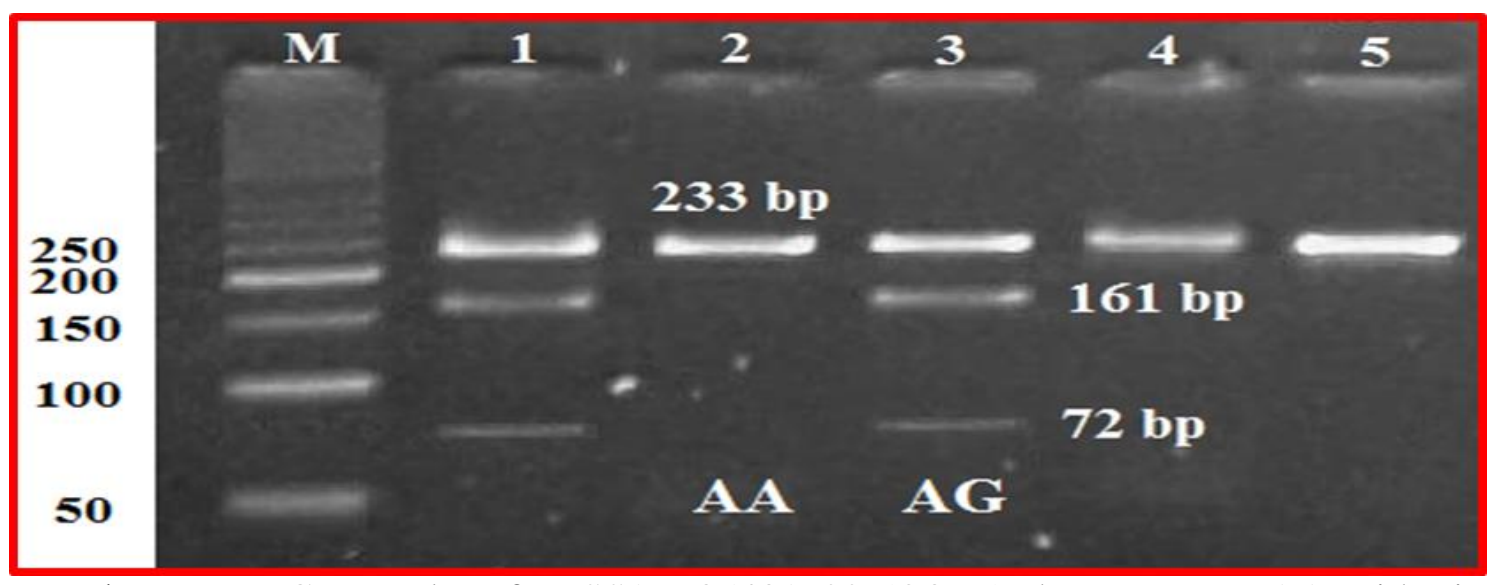

Figure 1- RFLP-PCR results of KISS1 rs35431622 (Q36R); homozygous AA with single band of 233 bp at lane 2, Lane 3 shows three bands of 233, 161 and 72 representing AG genotype. M: 100 bp DNA ladder

.The AA genotype was most common in both groups, while the AG was almost three times more frequent in the patients group. The frequencies of $A G$ genotype and $G$ allele were higher in patients compared with control group. Patients had high OR value of $\mathrm{G}$ allele (3.105) with 95\% CI: 0.365-26.399. According to these results, $\mathrm{G}$ allele may be considered as a risk factor, while A allele seems to be protective against male infertility in Iraqi population. The detailed results are outlined in Table 3.

Table 3-Distribution of gene polymorphism and allele frequency of KISS SNP rs35431622 (Q36R) in patient and control groups.

\begin{tabular}{|l|l|l|l|l|l|l|l|}
\hline \multirow{2}{*}{ Genotypes } & \multicolumn{2}{|l|}{ Patients No.(60 } & \multicolumn{2}{l|}{ Control No.(30) } & \multirow{2}{*}{ P value } & \multirow{2}{*}{ OR } & \multirow{2}{*}{ 95\% CI } \\
\cline { 2 - 5 } & No & Freq (\%) & No & *Freq (\%) & & & \\
\hline AA & 54 & 90 & 29 & 96.97 & - & 1 Ref. & - \\
\hline AG & 6 & 10 & 1 & 3.33 & 0.289 & 3.222 & $0.369-28.069$ \\
\hline GG & 0 & 0 & 0 & 0 & 0 & 0 & 0 \\
\hline Allele & No & Freq (\%) & No & Freq (\%) & P value & OR & 95\% CI \\
\hline A & 114 & 95 & 59 & 98.33 & \multirow{2}{*}{0.299} & 1 Ref. & - \\
\hline G & 6 & 5 & 1 & 1.67 & & 3.105 & $0.365-26.399$ \\
\hline
\end{tabular}

$A$ is a wild allele, $\quad G$ is a mutant allele. Freq = Frequency.

The AG genotype has significantly lower levels of the measured hormones (kisspeptin, testosterone, FSH, LH and prolactin) in the patients group when compared to the AA genotype, as shown in Table 4.

Table 4-Association of KISS SNP rs35431622 genotypes (Q36R) with the level of the hormones.

\begin{tabular}{|c|c|c|c|}
\hline Parameter & AA $($ No. 54) Mean \pm SD & AG (No. 6) Mean \pm SD & P-value \\
\hline Kisspeptin-54 $(\mathbf{n g} / \mathbf{m l})$ & $197.93 \pm 8.6$ & $171.43 \pm 8.7$ & 0.481 \\
\hline Testosterone $(\mathbf{n g} / \mathbf{m l})$ & $10.67 \pm 1.6$ & $8.23 \pm 1.4$ & 0.388 \\
\hline FSH $(\mathbf{m} \boldsymbol{\mu} / \mathbf{m l})$ & $8.51 \pm 0.9$ & $5.49 \pm 0.1$ & 0.3294 \\
\hline LH $(\mathbf{m} \boldsymbol{\mu} / \mathbf{m l})$ & $4.84 \pm 0.94$ & $5.42 \pm 0.65$ & 0.707 \\
\hline Prolactin $(\mathbf{n g} / \mathbf{m l})$ & $17.36 \pm 1.4$ & $14.38 \pm 0.9$ & 0.414 \\
\hline
\end{tabular}

Our second target was the kisspepptin-54 hormone, studying its polymorphism at codon 81 rs4889 (C/G). There was a correlation between the CC genotype and the patients group, but it was non-significant. Patients had an OR value of CC genotype of 2.5 with $95 \%$ CI: $0.21-$ 29.26, whereas the OR value of C allele was 1.14 with $95 \%$ CI: $0.613-2.135$ ). Hence, CC genotype may be considered as a risk factor for male infertility in the Iraqi population. Table 
5 includes the frequency for each genotype and allele and the OR value, while Figure 2 shows representative samples of each genotype.

Table 5-Genotyping of KISS1 SNP rs4889 (81C/G, C/C, G/G) in both patients and control groups.

\begin{tabular}{|c|c|c|c|c|c|c|c|}
\hline \multirow{2}{*}{ Genotype } & \multicolumn{2}{|c|}{ Patients No. (60 } & \multicolumn{2}{|c|}{ Control No. (30) } & \multirow{2}{*}{ P value } & \multirow{2}{*}{ OR } & \multirow{2}{*}{ 95\% CI } \\
\cline { 2 - 5 } & No. & Freq (\%) & No. & Freq (\%) & & & \\
\hline CC & 4 & 6.66 & 1 & 3.33 & & 2.5 & $0.21-29.26$ \\
\hline CG & 48 & 80 & 24 & 80 & \multirow{2}{*}{0.758} & 1.25 & $0.37-4.23$ \\
\hline GG & 8 & 13.34 & 5 & 16.67 & & 1 Ref. & - \\
\hline Allele & No. & Freq (\%) & No. & Freq (\%) & P value & OR & 95\% CI \\
\hline C & 56 & 46.67 & 26 & 43.33 & & 1.14 & $0.613-2.135$ \\
\hline G & 64 & 53.33 & 34 & 56.67 & \multirow{2}{*}{0.672} & 1 Ref. & - \\
\hline
\end{tabular}

G is a wild allele, $\quad C$ is a mutant allele. Freq $=$ Frequency.

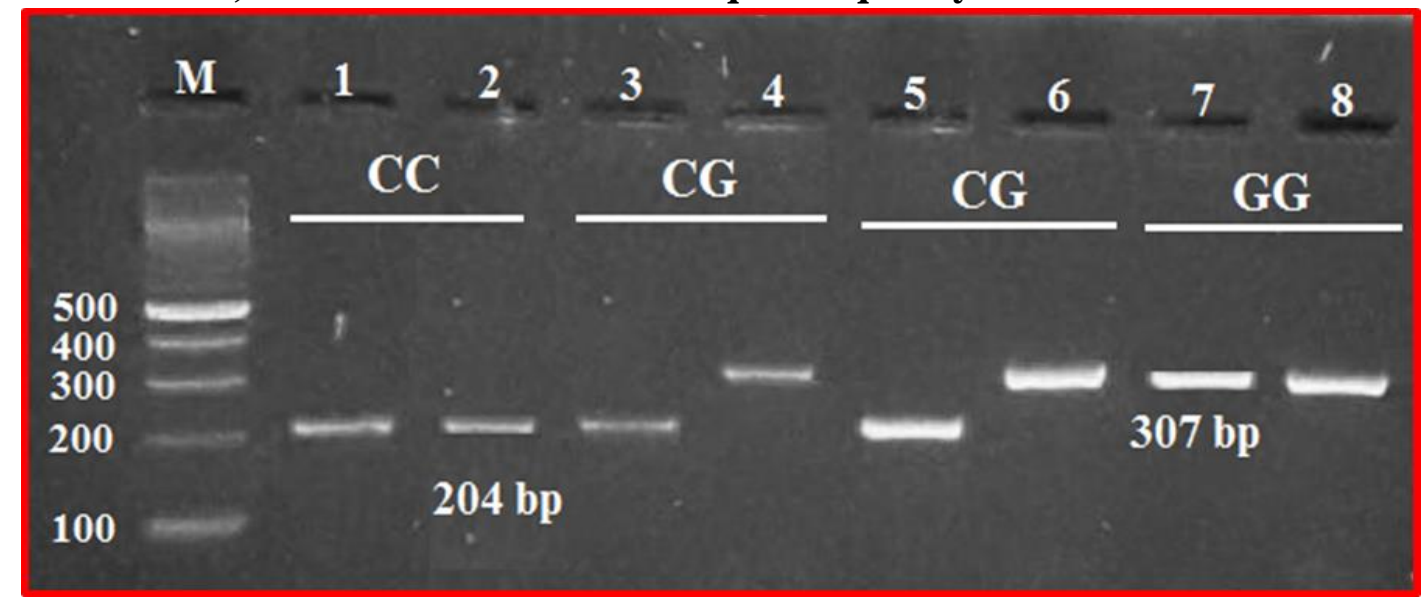

Figure 2 - ARMS-PCR results of KISS1 gene codon 81 (rs4889). Homozygous CC is shown in lanes 1 and 2 with a single band of $204 \mathrm{bp}$; homozygous GG is in lanes 7 and 8 with a single band of 307 bp; heterozygous CG is in lanes 3,4 and 5,6 with double bands of 204 and $307 \mathrm{bp}$, respectively.

The second step in this direction was to test whether the above genotype influences or is associated with the level of studied hormones in the patients group. There was no significant difference in the level of the hormones among the different genotypes. Table 6 gives a detailed numerical description of the levels of each hormone in the different genotypes.

Table 6 -Association of KISS1 SNP rs3889 (81 C/G, C/C, G/G) with the levels of the studied hormones

\begin{tabular}{|c|c|c|c|c|}
\hline Parameter & $\begin{array}{c}\text { CC }(\text { No. 4) } \\
\text { Mean } \pm \text { SD }\end{array}$ & $\begin{array}{c}\text { CG (No. 48) } \\
\text { Mean } \pm \text { SD }\end{array}$ & $\begin{array}{c}\text { GG (No. 8) } \\
\text { Mean } \pm \text { SD }\end{array}$ & P value \\
\hline Kisspeptin-54 (ng/ml) & $224.9 \pm 9.18$ & $199.21 \pm 8.9$ & $156.86 \pm 6.35$ & 0.347 \\
\hline Testosterone $(\mathbf{n g} / \mathbf{m l})$ & $10.39 \pm 1.2$ & $8.67 \pm 0.3$ & $6.31 \pm \mathbf{0 . 5}$ & 0.536 \\
\hline FSH $(\mathbf{m} \boldsymbol{\mu} / \mathbf{m l})$ & $7.50 \pm 0.1$ & $5.99 \pm 0.5$ & $3.72 \pm 0.2$ & 0.631 \\
\hline LH $(\mathbf{m} \boldsymbol{\mu} / \mathbf{m l})$ & $5.58 \pm 0.3$ & $5.40 \pm 0.7$ & $5.05 \pm 0.6$ & 0.960 \\
\hline Prolactin $(\mathbf{n g} / \mathbf{m l})$ & $14.84 \pm 1.4$ & $13.78 \pm 1.2$ & $19.97 \pm 1.0$ & 0.154 \\
\hline
\end{tabular}

We finally tried to identify the relation between the levels of kisspepetin and the sex hormones in the patients group. As can be seen in Table 7, there was a non-significant positive correlation for kisspeptin with LH, FSH and testosterone, while its correlation to prolactin was negative. 
Table 8-Association of Kisspeptin with the levels of the hormones

\begin{tabular}{|c|c|c|c|}
\hline \multirow{4}{*}{ Kisspeptin-54 (ng/ml) } & Parameter & R-factor & P value \\
\cline { 2 - 4 } & Testosterone $(\mathbf{n g} / \mathbf{m l})$ & -0.0375 & 0.776 \\
\cline { 2 - 4 } & FSH $(\mathbf{n g} / \mathbf{m l})$ & 0.129 & 0.327 \\
\cline { 2 - 4 } & LH $(\mathbf{n g} / \mathbf{m l})$ & 0.204 & 0.118 \\
\cline { 2 - 4 } & Prolactin $(\mathbf{n g} / \mathbf{m l})$ & -0.085 & 0.519 \\
\hline
\end{tabular}

\section{Discussion}

Infertility is a common medical and social concern. Male partner contributes to about one third of the cases; male abnormalities include oligo-, astheno-, and terato- spermia in different combinations. However, there is a medical case where no abnormality can be found in the seminal fluid of the partner, which is termed idiopathic infertility. Advances in molecular biology brought the possibility of detecting genetic variations in the fertility stage.

Kisspeptin is involved in the pituitary- hypothalamic regulation. The low serum level of kisspeptin-54 in the infertile group can be explained, partly, by either low number of cells expressing the kisspeptin mRNA or reduced expression by individual cells. Post- translational changes might be a player in this field. Other studies have found that kisspeptin is lower in infertile males[19-20]. Our study is unique in its setting as subjects of our infertile male group have idiopathic infertility. This means that kisspeptin-54 does not only influence the sperm number and activity, but might also affect sperm maturation and fertilization ability.

Lower kisspepetin-54 level, which was associated with low levels of LH, FSH and Testosterone, was observed in our study. This has a logical explanation, since kisspeptin is a regulator of gonadotropin- releasing hormone which in return stimulates LH, FSH, and Testosterone. We can assume that the change in the level of kisspeptin I is mainly due to a reduction in its hypothalamic secretion, since other tissues have minor contribution to serum level [21].

Genetic analysis of the kisspeptin gene for variations in SNPs shows that some genotypes are associated with infertility, such as SNP rs35431622, where AA genotype changes to the heterozygous AG genotype at position 36 (Q36R). Different studies showed different outcomes; in Iran, no correlation was found between these changes and the unexplained female infertility [17]. Different studies were performed about Kisspeptinn SNPs, but not about this specific SNP.

These genetic changes were associated with a lower level of kisspeptin-54. Since this SNP has changed the amino acid sequence of the kisspeptin-54, this sequence change might have altered the expression, translation, or degradation of the protein. The changes in the other measured hormones are a direct result of change in kisspeptin-54.

The common genotype is a heterozygous CG, which accounts for almost $85 \%$ of the cases, which is similar to the distribution seen in an Iranian study [19]. Additionally, in line with the Iranian study, a correlation was found between the homozygous CC and GG genotypes and idiopathic infertility. The variations in the genotypes resulted in amino acid changes to proline/proline and arginine/arginine that might have changed the stability of the protein or its expression, with subsequent changes in its level. It was unexpected to find that CC genotype was associated with higher level of kisspeptin-54 and its downstream hormones while being still associated with infertility. Though no studies have examined such controversy, we might suggest a change in the function of the protein on yet unknown factors that influence sperm ability for fertilization or some type of linkage disequilibrium with other fertility factors.

In general, it seems that such SNP in different positions in kisspeptin-54 predisposes people carrying it to a higher rate of idiopathic infertility. The mechanism of this association requires further expanded genomic and proteomic studies on larger number of patients. 


\section{Acknowledgment}

Special thanks to the staff of the High Institute of Infertility Diagnosis and Assisted Reproductive Technologies of Al-Nahrain University for their unlimited help and support during our work.

\section{References}

[1] Carini, M. Fidock, and A. van Gool. Handbook of Biomarkers and Precision Medicine. CRC Press, 2019.

[2] F. Zegers-Hochschild et al. "The international committee for monitoring assiste reproductive technology (ICMART) and the world health organization (WHO) revised glossary on ART terminology." Hum. Reprod., vol. 24, no. 11, pp. 2683-2687, 2009.

[3] La Marca, A. and E. Mastellari. Infertility, in Female Reproductive Dysfunction, F. Petraglia and B.C.J.M. Fauser, Editors, Springer International Publishing: Cham. 2020. p. 1-23.

[4] A. Ferlin and C. Foresta. "Infertility: practical clinical issues for routine investigation of the male partner," J. Clin. Med., vol. 9, no. 6, pp. 1644, 2020.

[5] Ali, M. H., \& Al-Kazaz, A. K. A. "Molecular detection of Chlamydia trachomatis infection among males with abnormal semen". Iraqi Journal of Science, pp. 2005-2011, 2018.

[6] A. Hamada, S. C. Esteves, M. Nizza, and A. Agarwal. "Unexplained male infertility: diagnosis and management," Int. braz j urol, vol. 38, no. 5, pp. 576-594, 2012.

[7] H. Zhang et al. "A single nucleotide polymorphism in a miR-1302 binding site in CGA increases the risk of idiopathic male infertility," Fertil. Steril., vol. 96, no. 1, pp. 34-39, 2011.

[8] R. Rehman, Z. Jamil, S. S. Fatima, and F. Alam. "Silent mutation in KISS1 and KISS1R and unexplained infertility," Avicenna J. Med. Biochem., vol. 3, no. 2, 2015.

[9] Q. Tang et al. "Idiopathic male infertility and polymorphisms in the DNA methyltransferase genes involved in epigenetic marking," Sci. Rep., vol. 7, no. 1, pp. 1-7, 2017.

[10] Mahmoud, S. T. M., Alkazaz, A. K. A., \& Al-Musawi, B. J. The Impact of LHR Gene Polymorphism Rs12470652 in Women with POF and Nihh, A Case-Control Study. Iraqi Journal of Science, pp. 508-516, 2020.

[11] Y. Cao, Z. Li, W. Jiang, Y. Ling, and H. Kuang. "Reproductive functions of Kisspeptin / KISS1R Systems in the Periphery," pp. 1-10, 2019.

[12] M. Kotani et al. "The metastasis suppressor gene KiSS-1 encodes kisspeptins, the natural ligands of the orphan G protein-coupled receptor GPR54," J. Biol. Chem., vol. 276, no. 37, pp.34631-34636, 2001.

[13] X. Luan et al. "Association study of the polymorphisms in the KISS1 gene with central precocious puberty in Chinese girls," Eur. J. Endocrinol., vol. 157, no. 1, pp. 113-118, 2007.

[14]F. S. Albalawi, M. H. Daghestani, M. H. Daghestani, A. Eldali, and A. S. Warsy. "rs4889 polymorphism in KISS1 gene, its effect on polycystic ovary syndrome development and anthropometric and hormonal parameters in Saudi women," J. Biomed. Sci., vol. 25, no. 1, 2018.

[15] R. Rehman, S. S. Fatima, F. Alam, M. Ashraf, and S. Zafar. "Kisspeptin and attributes of infertile males and females: A cross-sectional study in a subset of Pakistani population, Andrologia, vol. 51, no. 9, p. e13370, 2019.

[16] O.-H. T. años del Grupo. "World Health Organization manual for the processing of human semen-2010," actas urol esp, vol. 34, no. 7, pp. 577-578, 2010.

[17] H. Vaziri, A. Rafeie, and Z. Siapoosh. "Q36R (rs 35431622) Polymorphism in KISS1 gene and idiopathic female infertility in a Northern Iranian population," Gene, Cell Tissue, vol. 4, no. 3, 2017.

[18] M. SEMNANI, H. VAZIRI, Z. Salehi, and M. A. HAMIDI. "The Association of Codon 81Polymorphism of KISS1 Gene with Idiopathic Male Infertility", 2013

[19] M. Kotani, F. Katagiri, T. Hirai, and J. Kagawa. "Plasma kisspeptin levels in male cases with hypogonadism," Endocr. J., pp. EJ14-0137, 2014.

[20] M. H. Ramzan et al. "Insight into the serum kisspeptin levels in infertile males," Arch. Iran. Med., vol. 18, no. 1, 2015.

[21] H. Clarke, W. S. Dhillo, and C. N. Jayasena. "Comprehensive review on kisspeptin and its role in reproductive disorders," Endocrinol. Metab., vol. 30, no. 2, pp. 124-141, 2015. 